\title{
A Survey on the English Learning Strategy of the Rural High School Students and Urban High School Students
}

\author{
Yanfeng $\mathrm{Hu}$ \\ Foreign Language Department, Dezhou University \\ Dezhou 253023, China \\ Tel: 86-534-898-5363Ｅ-mail: huyanfeng7548@sina.com
}

The research is financed by Dezhou University and National Basic Foreign Language Teaching Research Centre, No.JJWYZCYB2007025.

\begin{abstract}
This paper aims to investigate the overall characteristics of the rural and urban high school students' learning strategy selection and use. The results indicate that the general frequency of the subjects' learning strategies selection and use is not satisfying. Among the six learning strategies, the most used strategies are affective strategies, and the least used strategies by the subjects are social strategies. What's more, the research results show that the urban students, compared to the rural ones, do better in using all the strategies. But through T- test analysis we can find that there is only significant difference in the using of compensation and social strategies between them and no evident distinction exists between the two groups when using metacognitive, cognitive, affective and memory strategies.
\end{abstract}

Keywords: Survey, English learning strategy, Rural high school students, Urban high school students

\section{Introduction}

Since the early 1970's, a gradual but significant shift has taken place in the field of language teaching, resulting in less emphasis on teacher and teaching and greater stress on learners and learning. The theoretical impetus for examining how learners approach the task of learning a second language can be attributed to the changing views on the nature of mind which were put forward by the theory and research in the field of cognitive science. Some applied linguists and psychologists began to pay much more attention to the study of individual learner differences.

The first researcher who studied the learners' strategies was Aron Carton. He first pointed out that the different learners employed the different inference methods. Enlightened by his research, some linguists (Rubin 1975; Stern 1975; Naiman 1978) began to do some research on the characteristics of the successful language learners and meanwhile identify some learning strategies they employed in order to benefit the less successful language learners. Soon afterwards, the various definition taxonomies and research results on language learning strategies emerged constantly.

For the Chinese learners, their learning surroundings, learning goals, task requirements and their learning motivation are quite different from abroad. Whether the foreign research findings apply to the Chinese learners is still a question. Therefore, there is a great need to investigate the learning strategies among the Chinese students so that we have a better understanding of what characteristics of their learning strategies are and what learning strategies training they need to achieve their goals.

In contrast to the foreign researches, China developed the work in this field a bit later. Exactly speaking, some researches were conducted in the late 1980's. What's more, almost all the researches focused on not only the college students but also the English majors and few have been done among the middle school students at present. In the basic teaching stage, one task of the middles school English teaching is to help the learners to cultivate their good learning habit and effective learning strategies. The middle school students belong to an independent learning group, so the learning strategies they employ should possess their own particularity. Therefore, there is a great need for the educators to know clearly about the overall characteristics of the students' learning strategy selection and use so that the teachers can help them to form their proper learning strategies consciously and to improve their learning efficiency in the practical process of English teaching. Based on such a purpose, we adopt a questionnaire to investigate the learning strategies used among the rural and urban high school students, and then try to make clear the difference exists between $\underline{\text { them.. }}$

\section{Research Method}

Considering the characteristics of this study, that is, we are going to investigate the learning strategy use among the rural and urban high school students, and additionally, owing to the limitation of time, space funds and personnel, a survey method is adopted. 


\subsection{The sample for the investigation}

The subjects of the study are 300 rural high school students and 300 urban high school students. They are selected randomly from two schools: Qingyun No.2 middle school, which is rural school; Dezhou No.1 middle school, which is urban school. All the subjects have had the experience of at least 4 years in language learning. In the class, I asked them to complete the research papers I handed out. I also emphasized that there were no right or wrong answers and what they ought to do was just to circle the answers which accorded with their facts.

\subsection{Instrument}

The questionnaire contains two sections. Section I is on the background information which is intended to help the researcher better understand the results of the survey in context. It includes name, gender, age, English achievement, school type, and the cultural background and career of their parents. Section II is on language learning strategy use. The Strategy Inventory for Language Learning Version 7.0 (SILL) developed by Oxford (1990) is adopted. On this basis some necessary revision has been made so as to adapt to the Chinese students. Meanwhile the SILL has been translated into Chinese, so that there will be no difficulty for the subjects in understanding them. The SILL adopts Likert Scale, containing 60 items, each with 5 choices ranging from 'the statement is never true or usually not true or somewhat true of me' to the statement is usually or always true of me'.

These 60 items are divided into 6 categories according to the strategy classification system put forward by Oxford (1990): metacognitive strategies (1-10); cognitive strategies (11-20); memory strategies (21-30); compensation strategies (31-40); affective strategies (41-50); social strategies (51-60).

After the questionnaire was finished, 69 invalid papers were abandoned, and 531 papers were collected altogether. The related data was conducted by SPSS 10.0.

\section{Results and discussion}

\subsection{Frequencies for strategies}

A descriptive analysis has been conducted to compare the frequencies for the strategy use of the high school students, that is, the mean scores of the six types of learning strategies are calculated by the computer. According to Oxford's calculating method, the mean from 1.0 to1.4 stands for never using this strategy; the mean from 1.5 to 2.4 stands for usually not using this strategy; the mean from 2.5 to 3.4 stands for sometimes using this strategy; the mean from 3.5 to 4.4 stands for usually using this strategy; and the mean from 4.5 to 5.0 stands for always using this strategy. The mean from 1.0 to 2.4 means the low frequency; the mean from 2.5 to 3.4 means the middle frequency and the mean from 3.5 to 5.0 means high frequency. Table 1 presents us with the overall frequencies of the subjects' learning strategy selection and use.

Generally speaking, the result of the investigation is not satisfying. According to the table above, through calculating, the general means is 3.247, which indicates the frequency of the students' learning strategy selection and use is in the middle level as a whole. Of the six strategies, the frequency of the students' using affective strategies is highest, and its mean reaches 3.569 , belonging to the range of high frequency. Affective strategies are very important for the language learning, which can help learners to gain control over such factors as emotions, attitude, motivation and value. Such result indicates that the majority of the students have been aware of the importance of English learning and meanwhile they have the positive attitude towards it. But this finding is inconsistent with some foreign researchers, for example, Chamot et al. (1987) found that the powerful affective strategies are woefully underused---reported by about 1 in every 20 language learners. Metacognitive strategies contain three sets: centering the learning, arranging and planning for learning and evaluating the learning, which can provide a way for the learners to coordinate their learning process. In this study, although the mean of metacognitive strategies is 3.430 , belonging to the range of middle frequency, but of all the strategies, the frequency of metacognitive strategies use is the second, which indicates the subjects can manage, monitor and evaluate their learning process basically. This result is likely to be related to their age. Generally speaking, compared to the junior middle school students, the subjects have clearer learning objectives, and the better capacity in self-monitoring, self-management and self evaluation. On the other hand, as we all know that the Chinese students, especially the rural ones, almost all have a higher expectation towards learning and the majorities are high motivated. So they possess a definite learning goal, and know well about the importance and utility of the learning. According to Atkingson's expectancy-value theory, people are more motivated to learn when they believe learning will lead to positive outcomes and when they value the positive outcomes. Nae-Dong Yang (1999) found that self-efficacy beliefs (the expectancy component of motivation) and intrinsic value (the students' goal for the task as well as their beliefs about the importance, utility and interest of the task) are both positively related to the use of metacognitive strategies.

As to cognitive strategies, memory strategies and compensation strategies, their means are 3.379, 3.276 and 3.089 respectively, which indicates the frequency of the subjects' strategies selection and use belongs to the middle level. Such results are normal. It is well known that the teaching goal in the middle school is to make the students possess some abilities in listening, speaking reading and writing. In order to reach it, the students therefore often employ some 
cognitive strategies, such as saying or doing something over and over again; taking notes; comparing elements of the new language with elements of Chinese to determine similarities and dissimilarities and so on. Memory strategies such as grouping or using images have a highly specific function: helping students store and retrieve new information. That reason why the subjects in this study employ memory strategies more frequently is that memory has already been regarded as an effective learning method in the Chinese traditional culture.

The findings also show the least used strategies by the subjects are social strategies, which is inconsistent with some foreign research results. Social strategies are very important because language is a kind of a social behavior, which help the learners learn through interaction with others, such as asking questions or cooperating with others. That the Chinese high school students are reported using them less frequently may be related to their learning situation. As is known to all, English in China is not a second language, but a foreign one. The students learn it only in a very formal setting, that is, in the classroom. Besides it's much harder to find or create any opportunity to learn the language in the natural environments. So there are no real communicative settings for the learners either in the classroom or out of it. What's more, spoken English is not yet the necessity in the system of the formal examinations. Therefore, Both the teachers and the students have neglected the training of social strategies.

\subsection{The differences between urban students and rural students}

In this section a T-test has been conducted so as to compare the differences in the use of learning strategies between the urban students and rural students.

From table 2 we can find that the mean scored by the urban students is higher in using all the strategies, that's the city school students, compared to the rural ones, do better in using all the strategies. But through T- test analysis shown in table 3 and table 4 we can see that there is only significant difference in the using of compensation and social strategies between them and no evident distinction exists between the two groups when using metacognitive, cognitive, affective and memory strategies.

Compensation strategies are such strategies as enable learners to use the new language for either compensation or production despite limitations in knowledge. The intention of the strategies is to make up for an inadequate mastery of grammar and especially, vocabulary. Compensation strategies are so important and necessary that they should be considered to be an essential part in the process of language learning. The reason why the significant differences exist between the two groups may be related to the teachers' teaching activities and the subjects' studying motivation.

Undoubtedly, the teaching level in the rural areas is obviously lower than that in the urban areas. In the classroom, mainly the native language dominates the whole teaching process, including the bilateral activities between the teachers and students. Therefore it is quite natural the compensation strategies, such as using mime, gesture, circumlocution and synonym are employed less frequently in such condition. In addition, according the former's research, we know the integrative motivation and social-group- identification motivation is stronger for the urban students, which makes them pay much more attention to speaking ability. For this reason whenever they meet with some barriers in communicating with others, they always manage to reach the goal by some ways, such as using body language or circumlocution or synonym.

As to the social strategies, the result shows that the urban students use them more frequently than the rural ones. Maybe this is related to their learning surroundings. Naturally, there are much more chances for the urban students in spite of in the classroom or out of it to cooperate with the proficient language users, besides, it is their integrative and social-group-identification motivation that spur them to employ some more social strategies, such as empathizing with others and so on.

\section{Conclusion and implication}

This paper is motivated by the question of how learning strategies are used by the high school students and what difference exist between the urban and rural high school students in using the learning strategies. Based on Oxford's learning strategy framework, we carried out this investigation. After conducting the data by SPSS 10.0, results are as follows: Among the six learning strategies, the most used strategies are affective strategies (3.569), then metacognitive strategies, cognitive strategies, memory strategies, and compensation strategies. The least used strategies by the subjects are social strategies. What's more, the research results show that the urban students, compared to the rural ones, do better in using all the strategies. But through T- test analysis we can find that there is only significant difference in the using of compensation and social strategies between them and no evident distinction exists between the two groups when using metacognitive, cognitive, affective and memory strategies. In a word, the general frequency of the subjects' learning strategies selection and use is not satisfying, which should be caused more attention by the educators. And meanwhile, such results also tell us a lesson that both in the rural high school and the urban one learning strategies training should be regarded as one crucial round of the teaching activities and accordingly some effective measures should be taken to promote the students' learning strategy selection and use consciously. Only by this way can the English achievements of the high school students be improved greatly. 


\section{References}

Chamot, A.U., Barnhardt,S., El-Dinary,P.B. and Robbins,J. (1999). TheLearning Strategies Handbook, White Plains, NY: Addison Wesley Longman.

Cohen,A.D. (2000). Strategies in Learning and Using a Second Language, Foreign Language Teaching \& Research Press.

Hake,Barry J. (1990). Lifelong Learning in Late Modernity: The Challenges to Society, Organizations and Individuals, Adult Education Quarterly, Vol. 49, No. 2.

Naiman, N. \& Frolich, M. et al. (1996). The Good Language Learner, Toronto: Modern Language Center.

Oxford,R.L. (1990). Language Learning Strategies: What Every Teacher Should Know, Boston, Mass: Heinle and Heinle.

O’Malley,J.M. \& Chamot,A.U. (1990). Learning Strategies in Second Language Acquisition, Cambridge: Cambridge University.

Table 1. The mean and standard deviation

\begin{tabular}{|l|l|l|l|l|l|}
\hline & N & Minimum & Maximum & Mean & $\begin{array}{l}\text { Std } \\
\text { Deviation }\end{array}$ \\
\hline metacognitive strategies & 531 & 10 & 63 & 3.430 & 5.30 \\
cognitive strategies & 531 & 12 & 62 & 3.379 & 5.34 \\
memory strategies & 531 & 17 & 70 & 3.276 & 5.43 \\
compensation strategies & 531 & 14 & 72 & 3.089 & 6.22 \\
affective strategies & 531 & 10 & 50 & 3.569 & 5.27 \\
social strategies & 531 & 10 & 49 & 2.733 & 6.53 \\
\hline
\end{tabular}

Table 2. the mean and std-deviation

\begin{tabular}{|ll|l|l|l|}
\hline & & $\mathrm{N}$ & Mean & Std Deviation \\
\hline metacognitive & urban & 263 & 3.298 & 5.28 \\
strategies & rural & 268 & 3.272 & 5.42 \\
\hline cognitive & urban & 263 & 3.331 & 5.14 \\
strategies & rural & 268 & 3.228 & 5.31 \\
\hline memory & urban & 263 & 3.191 & 5.38 \\
strategies & rural & 268 & 3.169 & 6.49 \\
\hline compensation & urban & 263 & 3.229 & 5.72 \\
strategies & rural & 268 & 3.017 & 5.27 \\
& & & \\
\hline affective & urban & 263 & 3.511 & 5.79 \\
strategies & rural & 268 & 3.448 & 5.96 \\
\hline social & urban & 263 & 2.861 & 6.50 \\
strategies & rural & 268 & 2.603 & 6.51 \\
\hline
\end{tabular}

Table 3. Levene's test for equality of variances

\begin{tabular}{|ll|l|l|}
\hline \multirow{2}{*}{ metacognitive strategies } & \multicolumn{2}{l|}{ Levene's Test for equality of variances } \\
\cline { 3 - 4 } & $\begin{array}{c}\text { Equal variances assumed } \\
\text { Equal variances not assumed }\end{array}$ & 1.272 & .260 \\
\hline cognitive strategies & $\begin{array}{c}\text { Equal variances assumed } \\
\text { Equal variances not assumed }\end{array}$ & 1.367 & .243 \\
\hline memory strategies & $\begin{array}{l}\text { Equal variances assumed } \\
\text { Equal variances not assumed }\end{array}$ & .576 & .448 \\
\hline compensation strategies & $\begin{array}{l}\text { Equal variances assumed } \\
\text { Equal variances not assumed }\end{array}$ & 7.609 & .006 \\
\hline affective strategies & $\begin{array}{l}\text { Equal variances assumed } \\
\text { Equal variances not assumed } \\
\text { Equal variances assumed } \\
\text { Equal variances not assumed }\end{array}$ & 1.312 & .238 \\
\hline social strategies & & 5.200 & .020 \\
\hline
\end{tabular}


Table 4. T-test for equality of mean

\begin{tabular}{|c|c|c|c|c|c|}
\hline & & T-test & uali & & \\
\hline & & $\mathrm{t}$ & $\mathrm{df}$ & $\begin{array}{l}\text { Sig. } \\
\text { (2-tailed) }\end{array}$ & $\begin{array}{l}\text { Mean } \\
\text { Difference }\end{array}$ \\
\hline $\begin{array}{l}\text { metacognitive } \\
\text { strategies }\end{array}$ & $\begin{array}{l}\text { Equal variances assumed } \\
\text { Equal variances not assumed }\end{array}$ & 1.272 & & & .260 \\
\hline $\begin{array}{l}\text { cognitive } \\
\text { strategies }\end{array}$ & $\begin{array}{l}\text { Equal variances assumed } \\
\text { Equal variances not assumed }\end{array}$ & 1.367 & & & .243 \\
\hline $\begin{array}{l}\text { memory } \\
\text { strategies }\end{array}$ & $\begin{array}{l}\text { Equal variances assumed } \\
\text { Equal variances not assumed }\end{array}$ & .576 & & & .448 \\
\hline $\begin{array}{l}\text { compensation } \\
\text { strategies }\end{array}$ & $\begin{array}{l}\text { Equal variances assumed } \\
\text { Equal variances not assumed }\end{array}$ & 7.609 & & & .006 \\
\hline $\begin{array}{l}\text { affective } \\
\text { strategies }\end{array}$ & $\begin{array}{l}\text { Equal variances assumed } \\
\text { Equal variances not assumed }\end{array}$ & 1.312 & & & .238 \\
\hline $\begin{array}{l}\text { social } \\
\text { strategies }\end{array}$ & $\begin{array}{l}\text { Equal variances assumed } \\
\text { Equal variances not assumed }\end{array}$ & 5.200 & & & .020 \\
\hline
\end{tabular}

